\title{
Guru dan Orang Tua dalam Interaksi Edukatif
}

\author{
Sy. Bariah ${ }^{1 *}$ \\ ${ }^{1}$ Kementerian Agama Kota Pangkalpinang Bangka Belitung, Indonesia
}

\begin{abstract}
Abstrak: Penelitian ini bertujuan membahas pola interaksi edukatif antara guru dan orang tua serta anak didik sebagai upaya mencapai tujuan pendidikan. Metode penelitian yang digunakan adalah kualitatif dengan pendekatan studi pustaka. Penelitian ini menyimpulkan bahwa interaksi edukatif adalah hubungan dua arah antara guru dan anak didik dengan sejumlah norma sebagai mediumnya untuk mencapai tujuan pendidikan. Guru dan orang tua merupakan unsur yang terlibat dalam interaksi edukatif, karena keduanya memiliki peran penting dalam terbentuknya sebuah hubungan pendidikan yang efektif. Komunikasi yang efektif antara orang tua dan guru dibutuhkan dalam rangka menyamakan persepsi kedua belah pihak tentang hal yang dibutuhkan dalam pendidikan anak. Semua kegiatan yang memiliki tujuan, yang memiliki pesan, adanya individu atau kelompok yang aktif, adanya individu atau kelompok yang melaksanakan, adanya metode untuk mencapai tujuan, adanya situasi dan kondisi yang memungkinkan untuk terlaksanannya proses belajar mengajar yang baik, adanya penilaian atau evaluasi terhadap hasil interaksi, maka kegiatan itu bisa tergolong kegiatan yang relevan atau sesuai dengan kegiatan yang berupa interaksi yang bernilai edukatif.
\end{abstract}

Kata Kunci: guru, orang tua, interaksi edukatif

\begin{abstract}
This study aims to discuss patterns of educational interactions between teachers and parents and students as an effort to achieve educational goals. The research method used is qualitative with a literature study approach. This study concludes that educational interaction is a two-way relationship between teachers and students with a number of norms as a medium to achieve educational goals. Teachers and parents are elements involved in educational interactions, because both have an important role in the formation of an effective educational relationship. Effective communication between parents and teachers is needed in order to equalize the perceptions of both parties about what is needed in children's education. All activities that have a purpose, which have a message, the existence of an active individual or group, the existence of an individual or group that carries out, the method to achieve the goal, the situation and conditions that allow for the implementation of a good teaching and learning process, the existence of an assessment or evaluation of the results interaction, then these activities can be classified as relevant activities or in accordance with activities in the form of interactions that have educational value.
\end{abstract}

Keywords: teachers, parents, educational interactions

\section{Pendahuluan}

Kecenderungan manusia untuk berinteraksi atau berhubungan, melahirkan komunikasi dua arah melalui bahasa yang mengandung tindakan dan perbuatan. Karena ada aksi dan reaksi, maka interaksi pun terjadi. Karena itu, interaksi akan berlangsung bila ada

\footnotetext{
* Corresponding Author: Sy. Bariah (rahmatbarid30@gmail.com). Kementerian Agama Kota Pangkalpinang Bangka Belitung, Indonesia
} p-ISSN 2303-2952; e-ISSN 2622-8491 http://jurnal.radenfatah.ac.id/index.php/intelektualita 
hubungan timbal balik antara dua orang atau lebih. Namun perlu diingat, interaksi sebagaimana disebutkan di atas, bukanlah interaksi edukatif, karena interaksi itu tidak mempunyai tujuan yang jelas. Kedua belah pihak tidak bermaksud untuk mengubah tingkah laku dan perbuatan lawan bicaranya. Mereka melakukan interaksi dengan tujuan masingmasing. Karena itu, interaksi antara manusia selalu mempunyai motif-motif tertentu guna memenuhi tuntutan hidup dan kehidupan mereka masing-masing. Interaksi yang berlangsung di sekitar kehidupan manusia dapat diubah menjadi "interaksi yang bernilai edukatif”, yakni interaksi yang dilakukan dengan sadar meletakkan tujuan untuk mengubah tingkah laku dan perbuatan seseorang. Interaksi yang bernilai pendidikan ini dalam dunia pendidikan disebut sebagai "interaksi edukatif" (Fahyani \& Istikomah, 2016)

Belajar mengajar adalah sebuah interaksi yang bernilai normatif. Belajar mengajar adalah suatu proses yang dilakukan dengan sadar dan bertujuan. Tujuan adalah sebagai pedoman ke arah mana akan dibawa proses belajar menganjar. Proses belajar menganjar akan berhasil bila hasilnya mampu membawa perubahan dalam pengetahuan-pemahaman, keterampilan, dan nilai-sikap dalam diri anak didik. Interaksi belajar mengajar dikatakan bernilai normatif karena di dalamnya ada sejumlah nilai. Jadi, adalah wajar bila interaksi itu dinilai bernilai edukatif. Bagaimana sikap dan tingkah laku guru yang edukatif? Guru yang dengan sadar berusaha untuk mengubah tingkah laku, sikap, dan perbuatan anak didik menjadi lebih baik, dewasa, dan bersusila yang cakap adalah sikap dan tingkah laku guru yang bernilai edukatif. Dalam interaksi edukatif unsur guru dan anak didik harus aktif, tidak mungkin terjadi proses interaksi edukatif bila hanya satu unsur yang aktif. Aktif dalam arti sikap, mental, dan perbuatan. Dalam sistem pengajaran dengan pendekatan keterampilan proses, anak didik harus lebih aktif dari pada guru. Guru hanya bertindak sebagai pembimbing dan fasilitator. Ada tiga pola komunikasi antara guru dan anak didik dalam proses interaksi edukatif, yakni komunikasi sebagai aksi, komunikasi sebagai interaksi, dan komunikasi sebagai transaksi. Komunikasi sebagai aksi atau komunikasi satu arah menempatkan guru sebagai pemberi aksi dan anak didik sebagai penerima aksi. Guru aktif, dan anak didik pasif. Mengajar dipandang sebagai kegiatan menyampaikan bahan pelajaran.

Dalam komunikasi sebagai interaksi atau komunikasi dua arah, guru berperan sebagai pemberi aksi atau penerima aksi. Demikian pula halnya anak didik, bisa sebagai penerima aksi, bisa pula sebagai pemberi aksi. Antara guru dan anak didik akan terjadi dialog (Fahyani \& Istikomah, 2016).

Proses pembelajaran merupakan suatu kegiatan dimana melibatkan orang lain untuk membantunya, siapapun tidak akan pernah menyangkal bahwa kegiatan pembelajaran tidak berproses dalam kehampaan tetapi terdapat sejumlah norma untuk dipatuhi. Guru yang mengajar dan anak didik yang belajar perpaduan kedua unsur manusiawi ini lahirlah interaksi edukatif dengan memanfaatkan bahan sebagai alat untuk pengajarannya. Dalam proses pembelajaran itulah semua komponen dilibatkan secara optimal guna mencapai tujuan pengajaran yang telah ditetapkan (Ardayani, 2017).

Sekolah merupakan tempat terjadinya interaksi belajar antara guru dan siswa berupa 
serangkaian aktivitas belajar antara guru dan siswa atas dasar hubungan timbal balik yang berlangsung dalam situasi edukatif untuk mencapai tujuan tetentu. Interaksi atau hubungan timbal balik antara guru dan siswa merupakan syarat utama bagi berlangsungnya pendidikan. Dalam hal ini bukan hanya menyampaikan pesan berupa materi saja, melainkan penanaman sikap dan nilai pada diri siswa yang sedang belajar dalam rangka mencapai hasil belajar yang optimal (Santika, 2015)

\section{Tanggung Jawab Orang Tua terhadap Pendidikan Anak}

Menurut A. Samad Usman (2017), ada beberapa tanggung jawab orang tua terhadap pendidikan anak dalam ditinjau dari perspektif Islam, yaitu:

1. Memberi contoh kepada anak dalam berakhlak mulia. Sebab orang tua yang tidak berhasil menguasai dirinya tentulah tidak sanggup meyakinkan anak-anaknya untuk memegang akhlak yangdiajarkannya. Maka sebagai orang tua harus terlebih dahulu mengajarkan pada dirinya sendiri tentang akhlak yang baik sehingga baru bisa memberikan contoh pada anak-anaknya.

2. Menyediakan kesempatan kepada anak untuk mempraktikkan akhlak mulia. Dalam keadaan bagaimanapun, sebagai orang tua akan mudah ditiru oleh anak-anaknya, dan di sekolah pun guru sebagai wakil orang tua merupakan orang tua yang akrab bagi anak.

3. Memberi tanggung jawab sesuai dengan perkembangan anak. Pada awalnya orang tua harus memberikan pengertian dulu, setelah itu baru diberikan suatu kepercayaan pada diri anak itu sendiri.

4. Mengawasi dan mengarahkan anak agar selektivitas dalam bergaul. Jadi orang tua tetap memberikan perhatian kepada anakanak, dimana dan kapanpun orang tua selalu mengawasi dan mengarahkan, menjaga mereka dari teman-teman yang menyeleweng dan tempat-tempat maksiat yang menimbulkan kerusakan.

Berdasarkan pendapat di atas, maka dapat diketahui bahwa peran atau tanggung jawab orang tua sangat penting dan sentral bagi anak. Anak yang berusia sekolah dasar adalah anak yang mempunyai kemampuan imitasi yang tinggi. Kecenderungan ini mengharuskan orang tua untuk bisa mengarahkan dan mengawasi pertumbuhan dan perkembangan anak dengan baik dan bijak. Orang tua hendaknya memberikan contoh berperilaku dan berakhlak yang baik, dan memberikan kesempatan kepada anak untuk bisa mempraktekkan akhlak dan perilakuk yang baik. orang tua tetap memberikan perhatian kepada anak-anak, dimana dan kapanpun orang tua selalu mengawasi dan mengarahkan, menjaga mereka dari gangguan buruk dari lingkungan sekitar anak. Orang tua senantiasa melakukan interaksi dengan anak di lingkungan keluarga. Dalam interaksi tersebut hendaknya orang tua selalu memasukkan nilai-nilai yang edukatif, agar anak senantiasa mendapatkan perubahan yang positif dalam dirinya. Interaksi yang baik juga akan membuat anak lebih aktif dan lebih terbuka kepada orang tua dan secara tidak langsung, orang tua bisa melaksanakan tanggung jawabnya terhadap anaknya, yaitu tanggung jawab yang bernilai mendidik melalui interaksi edukatif.

Menurut Andi Syahraeni (2015), tanggung jawab orang tua terhadap anaknya dalam hal pengasuhan, pemeliharaan dan pendidikan anak, ajaran Islam menggariskannya sebagai berikut: 
1. Tanggung jawab pendidikan dan pembinaan akidah

Maksud tanggung jawab ini adalah mengikat anak dengan dasar-dasar keimanm, keislaman, sejak anak mulai mengerti dan dapat memahami sesuatu. Dasar-dasar keimanan dalam pengertian ini adalah segala sesuatu yang telah ditetapkan dengan jalan khabar secara benar berupa hakikat keimanan dan masalah gaib. Penanaman akidah ini, telah dicontohkan oleh para Nabi terdahulu, sebagaimana diceritakan oleh Allah dalam al Qur'an "Dan Ibrahim telah mewasiatkan ucapan itu kepada anak-anakmu, demikian pula Ya'qub. Ibrahim berkata 'Hai anak-anakku sesungguhnya Allah telah memilih agama ini bagimu, maka janganlah kamu mati kecuali dalam memeluk Islam"

Al-Ghazali mengemukakan, langkah pertama yang bisa diberikan kepada anak dalam menanamkan keimanan adalah dengan memberikan hafalan. Sebab proses pemahaman harus diawali dengan hafalan terlebih dahulu. Ketika menghafal akan sesuatu kemudian memahaminya, akan tumbuh dalam dirinya sebuah keyakinan dan akhirnya anak akan membenarkan apa yang telah dia yakini sebelumnya. Inilah proses pembenaran dalam keimanan yang dialami anak pada umumnya. Sedangkan di sisi lain ada pula yang telah Allah lebihkan pada sebagian anak lainnya. Allah telah menanamkan keimanan langsung dalam jiwa mereka, tanpa harus melewati pendidikan di atas.

Berdasarkan ungkapan al-Ghazali di atas, Nur al-Hafidz merumuskan empat pola dasar dalam pembinaan keimanan pada anak, yaitu, (1) senantiasa membacakan kalimat tauhid pada anak, (2) menanamkan kecintaan kepada Allah, kepada Rasulullah saw. (3) mengajarkan al
Quran, dan (4) menanamkan nilai-nilai pengorbanan dan perjuangannya.

Pakar kejiwaan, sebagaimana dikutip oleh Zakiyah Darajat menyatakan, setelah anak lahir, pertumbuhan jasmani anak berjalan cepat dan perkembangan akidah, kecerdasan, akhlak, kejiwaan, rasa keindahan dan kemasyarakatan anak (tujuh dimensi manusia), berjalan serentak dan seimbang. Si anak mulai mendapat bahanbahan atau unsur-unsur pendidikan serta pembinaanyang berlangsung tanpa disadari oleh orang tuanya. Mata si anak melihat dan merekam apa saja yang tampak olehnya. Rekaman tersebut tinggal dalam ingatan. Manusia belajar lewat penglihatan sebanyak $83 \%$.

Kemudian telinga juga segera berfungsi setelah ia lahir, dan menangkap apa yang sampai ke gendang telinganya. Dia mendengar bunyi, kata-kata, yang diucapkan olehibu, bapak, kakak dan orang lain dalam keluarga, atau suara dari radio, $\mathrm{TV}$, dan sebagainya. Lewat pendengaran itu, anak belajar sebanyak $11 \%$. Pertumbuhan kecerdasan anak sampai umur enam tahun masih terkait kepada alat indranya, maka dapat dikatakan bahwa anak pada umur (0-6 tahun) ini berpikir indrawi. Artinya, anak belum mampu memahami hal yang maknawi (abstrak). Oleh karena itu, pendidikan, pembinaan keimanan, dan ketakwaan anak belum dapat menggunakan kata-kata (verbal). 12 Akan tetapi, diperlukan contoh, teladan, pembiasaan, dan latihan yang terlaksana di dalam keluarga sesuai dengan pertumbuhan dan perkembangan anak yang terjadi secara alamiah.

2. Tanggung jawab pendidikan dan pembinaan akhlak

Tanggung jawab ini maksudnya adalah pendidikan dan pembinaan mengenai dasar- 
dasar moral dan keutamaan perangai, tabiat yang harus dimiliki anak sejak anak masih kecil, hingga ia dewasa atau mukallaf. Dalam salah satu Hadis yang diriwayatkan oleh Ibnu Abbas, Rasulullah saw. berkata, "Dekatilah anakanakmu dan didiklah serta binalah akhlakakhlaknya." Akhlak adalah implementasi dari iman dalam segala bentuk perilaku. Pendidikan dan pembinaan akhlak anak dalam keluarga dilaksanakan dengan contoh dan teladan dari orang tua. Contoh yang terdapat pada perilaku dan sopan santun orang tua dalam hubungan dan pergaulan antara ibu dan bapak, perlakuan orang tua terhadap anak-anak mereka, dan perlakuan orang tua terhadap orang lain di dalam lingkungan keluarga dan lingkungan masyarakat. Betapa besar pengaruh contoh dan perilaku orang tua pada anak, terlebih bagi anak usia 3-5 tahun. Perkataan, cara bicara, dan perilaku lain, juga cara mengungkapkanmarah, gembira, sedih dan lain sebagainya, dipelajari pula dari orang tuanya. Maka dari itu, akhlak, sopan santun dan cara menghadapi orang tuanya, banyak bergantung kepada sikap orang tua terhadap anak. Benjamin Spock mengemukakan, bahwa setiap individu akan selalu mencari figur yang dapat dijadikan teladan ataupun idola bagi mereka. Orang tua, padaumumnya merupakan teladan bagi anakanak mereka yang sejenis, serta idola bagi mereka yang berlainan jenis. Artinya, seorang ayah adalah teladan bagi anak laki-lakinya dan idola bagi anak perempuannya.

3. Tanggung jawab pemeliharaan kesehatan anak

Maksud dari tanggung jawab ini adalah berkaitan dengan pengembangan, pembinaan fisik anak agar anak menjadi anak yang sehat, cerdas, tangguh dan pemberani. Oleh karena itu, orang tua berkewajiban untuk memberi makan dengan makanan yang halal dan baik (halalan thayyiba), menjaga kesehatan fisik, membiasakan anak makan dan minum dengan makanan dan minuman yang dibolehkan dan bergizi. Dalam buku "Menggagas Fiqh Sosial" Ali Yafie mengutip penyataan Pemerintah RI tahun 1986, bahwa di Indonesia pada bidang kesehatan, ternyata dari seribu orangpenduduk rata-rata 40 orang di antaranya menderita sakit. Anak-anak di bawah usia 1 bulan merupakan kelompok umur yang paling banyak menderita sakit. Kemudian disusul oleh kelompok umur 1 hingga 4 tahun. Rata-rata kematian 10 orang dari 1000 penduduk untuk setiap tahunnya. $45 \%$ dari jumlah kematian tersebut terdiri dari anak-anak yang berusia 1 bulan hingga 5 tahun. Kemudian dari bayi lahir hidup 1000 bayi setiap tahun, sekitar $125-150$ bayi meninggal sebelum usia 1 tahun. Sementara untuk negara maju. Jumlah kematian bayi dari 1000 bayi lahir sehat, maksimal 20 yang meninggal di bawah 1 tahun.

4. Tanggung jawab pendidikan dan pembinaan intelektual

Tanggung jawab ini maksudnya adalah pembentukan dan pembinaan berpikir anak dengan segala sesuatu yang bermanfaat serta kesadaran berpikir dan berbudaya. Tanggung jawab intelektual ini berpusat pada tiga hal, yaitu: kewajiban mengajar, penyadaran berpikir dan kesehatan berpikir.

Tanggung jawab kepribadian dan sosial anak

Tanggung jawab ini maksudnya adalah kewajiban orang tua untuk menanamkan anak sejak kecil agar terbiasa menjalankan adab sosial dan pergaulan sesamanya. Ketika anak yang masih suci,orang-orang dewasa mempunyai perhatian yang besar kepadanya, maka jiwa sosial dan perhatianyang benar terhadap orang 
lain itulah yang akan tumbuh kuat di dalam jiwanya. Pembentukan kepribadian terjadi dalam masa yang panjang, sejak dalam kandungan sampai umur 21 tahun. Pembentukan kepribadian berkaitan erat dengan pembinaan iman dan akhlak. Secara umum pakar kejiwaan berpendapat bahwa kepribadian merupakan suatu mekanisme yang mengendalikan dan mengarahkan sikap dan perilaku seseorang. Sayidiman Suryohadiprojo mengemukakan bahwa, pengembangan diri dengan disiplin memperlihatkan satu fakta perbandingan keberhasilan yang dialami Taiwan, Korea Selatan, Hongkong dan Singapura, sebagai 4 negara yang telah berhasil lepas landas. Kunci keberhasilan yang dicapai negara-negara tersebut sesungguhnya tidak hanya karena tersedianya warga negara yang terdidik dan terlatih, tapi yang terutama adalah karena adanya disiplin nasional yang amat tinggi dari tiap warganya.

Dari pendapat di atas, maka dapat diketahui bahwa tanggung jawab keluarga (orang tua) yaitu mengikat anak dengan dasardasar keimanm, keislaman, sejak anak mulai mengerti dan dapat memahami sesuatu. Pendidikan dan pembinaan mengenai dasardasar moral dan keutamaan perangai, tabiat yang harus dimiliki anak sejak anak masih kecil, hingga ia dewasa atau mukallaf. Pengembangan, pembinaan fisik anak agar anak menjadi anak yang sehat, cerdas, tangguh dan pemberani. Oleh karena itu, orang tua berkewajiban untuk memberi makan dengan makanan yang halal dan baik (halalan thayyiba), menjaga kesehatan fisik, membiasakan anak makan dan minum dengan makanan dan minuman yang dibolehkan dan bergizi. Pembentukan dan pembinaan berpikir anak dengan segala sesuatu yang bermanfaat serta kesadaran berpikir dan berbudaya. menanamkan anak sejak kecil agar terbiasa menjalankan adab sosial dan pergaulan sesamanya. Semua tanggung jawab yang ada, dilakukan oleh orang tua terhadap anaknya dengan menggunakan cara berinteraksi kepada anak. Interaksi yang dibangun adalah interaksi yang baik, yaitu interaksi yang bernilai edukatif, agar anak bisa mendapatkan pemahaman dan penambahan pengetahuan yang bernilai postif dalam diri anak tersebut.

\section{Realita Tanggung Jawab Orang Tua Terhadap Pendidikan Anak}

Realita yang terjadi di lapangan mengenai tanggung jawab orang tua terhadap pendidikan anak (usia SD) di Indonesia secara nasional terdapat perbedaan disetiap wilayahnya. Bagi penduduk di wilayah perkotaan, khususnya kota besar untuk orang tua biasanya sangat peduli dengan pendidikan anaknya. Hal ini karena di wilayah perkotaan banyak menyediakan lembaga-lembaga pendidikan yang tergolong lebih baik jika dibandingkan dengan wilayah pelosok pedesaan. Oleh sebab itu, dengan adanya lembaga pendidikan yang bervariasi dan memiliki fasilitas yang lengkap dan baik, di wilayah perkotaan, orang tua memiliki peluang yang baik untuk menyekolahkan anak-anaknya di sekolah yang ada, baik itu di SD Negeri, Madrasah Diniyah, Madrasah Ibtidaiyah Negeri, Sekolah Dasar Islam Terpadu.

Sedangkan untuk wilayah pelosok pedesaan, orang tua tidak punya banyak pilihan. Biasanya dalam satu desa menyediakan satu sekolah dasar, namun, terkadang dalam satu kecamatan hanya memiliki satu sekolah dasar yang berbasis Islam, seperti Madrasah Ibtidayiah. Namun demikian, untuk di wilayah pedesaan biasanya orang tua dengan keterbatasan yang ada tetap bertanggung jawab 
untuk menyekolahkan anaknya, walaupun mereka hanya punya satu sekolah di desa mereka. Namun juga tidak bisa dipungkiri bahwa, baik di desa maupun di kota masih ditemukan orang tua yang tidak begitu menghiraukan pendidikan anaknya. Hal ini bisa kita lihat di pada keluarga yang tergolong miskin atau kurang mampu. Jangankan untuk menyekolahkan anaknya, untuk makan seharihari saja mereka tidak mampu. Oleh sebab itu, bagi orang tua yang tergolong miskin, terkadang mengabaikan tanggung jawabnya tentang pendidikan anaknya.

\section{Peran dan Tugas Guru dalam Lembaga Pendidikan}

Dalam pengertian sederhana, guru adalah orang yang memberikan ilmu pengetahuan kepada anak didik. Guru dalam pandangan masyarakat adalah orang yang melaksanakan pendidikan di tempat-tempat tertentu, tidak mesti di lembaga pendidikan formal, tetapi bisa juga di masjid, di surau/musala, di rumah, dan sebagainya. Guru memang menempati kedudukan yang terhormat di masyarakat. Kewibawaanlah yang menyebabkan guru dihormati, sehingga masyarakat tidak meragukan figur guru. Masyarakat yakin bahwa gurulah yang dapat mendidik anak didik mereka agar menjadi orang yang berkepribadian mulia. Dengan kepercayaan yang diberikan masyarakat, maka di pundak guru diberikan tugas dan tanggung jawab yang berat. Mengemban tugas memang berat. Tetapi lebih berat lagi mengemban tanggung jawab. Sebab tanggung jawab guru tidak hanya sebatas di dalam sekolah, tetapi juga di luar sekolah. Pembinaan yang harus guru berikan pun tidak hanya secara kelompok (klasikal), tetapi juga secara individual. Hal ini mau tidak mau menuntut guru agar selalu memperhatikan sikap, tingkah laku, dan perbuatan anak didiknya, tidak hanya di lingkungan sekolah tetapi di luar sekolah sekalipun (Fahyani \& Istikomah, 2016).

Guru adalah figur seorang pemimpin. Guru adalah sosok arsitektur yang dapat membentuk jiwa dan watak anak didik. Guru mempunyai kekuasaan untuk membentuk dan membangun kepribadian anak didik menjadi seorang yang berguna bagi agama, nusa, dan bangsa. Guru bertugas mempersiapkan manusia susila yang cakap yang dapat diharapkan membangun dirinya dan membangun bangsa dan negara. Jabatan guru memiliki banyak tugas, baik yang terikat oleh dinas maupun di luar dinas dalam bentuk pengabdian. Tugas guru tidak hanya sebagai suatu profesi, tetapi juga sebagai suatu tugas kemanusiaan dan kemasyarakatan. Adapun tugas guru yaitu

1. Tugas guru sebagai suatu profesi menuntut kepada guru untuk mengembangkan profesionalitas diri sesuai perkembangan ilmu pengetahuan dan teknologi. Mendidik, mengajar, dan melatih anak didik adalah tugas guru sebagai profesi.

2. Tugas guru sebagai pendidik berarti meneruskan dan mengembangkan nilainalai hidup kepada anak didik. Tugas guru sebagai pengajar berarti meneruskan dan mengembangkan ilmu pengetahuan dan teknologi kepada anak didik.

3. Tugas guru sebagai pelatih berarti mengembangkan keterampilan dan menerapkan dalam kehidupan demi masa depan anak didik (Eni Fariyatul dkk., 2016: 186).

Ummu Hany Almasitoh dalam kesimpulan jurnalnya mengatakan bahwa peran guru dalam lembaga pendidikan adalah sebagai berikut. 
1. Berubahnya paradigma pendidikan dari berfokus pada guru ke berfokus pada siswa, tugas guru tidak semakin berkurang tetapi justru semakin bertambah. Peran dan tugas guru adalah membentuk watak anak didik agar mampu berpikir kritis dan kreatif sehingga terbentuk manusia yang berakhlak mulia, cerdas, berbudi luhur.

2. Guru bukan ilmuan maupun teknolog tetapi memiliki tugas sebagai penyebarluas ilmu dan teknologi kepada anak didik di sekolah. Di hadapan anak didik, guru adalah "nyala lilin" dan "menara air" yang selalu menerangi dan member kehidupan bagi anak didiknya.

3. Dalam proses pendidikan, tugas guru adalah mencerdaskan anak didik dan membentuk sikap, perilaku, serta watak anak didik dan mengantarkannya ke depan pintu kesuksesan hidup.

4. Guru perlu meningkatkan profesionalismenya melalui berbagai cara, seperti menempuh studi lanjut ke jenjang S2 atau S3. Namun, agar mampu membuat perubahan secara signifikan, pendidikan lanjut seorang guru harus linier dengan pendidikan S1-nya (Almasitoh, 2014).

Sedangkan menurut Juhji, guru memiliki peran sebagai pendidik, pembimbing, pelatih, penasehat, pembaharu (inovator), model dan teladan, pribadi, peneliti, pendorong kreativitas, pembangkit pandangan (motivator), pekerja rutin, pemindah kemah, pembawa cerita, aktor, emansipator, pengawet, kulminator dan evaluator. Peran guru dalam perkembangan pendidikan meliputi: Pertama, menanamkan nilai (value) serta membangun karakter (character building) peserta didik secara berkelanjutan dan berkesinambungan. Kedua, sebagai sentral pembelajaran. Ketiga, memberi bantuan dan dorongan (supporter), tugas-tugas pengawasan dan pembinaan (supervisor) serta tugas-tugas yang berkaitan dengan mendisiplinkan anak. Keempat, menjadi "panutan" bagi lingkungannya yang perlu diikuti dan ditaati. Pelaksanaan peran guru dalam perkembangan pendidikan dan pembelajaran yang memberikan perubahan pada peserta didik pada aspek pengetahuan (kognitif), sikap (afektif), dan keterampilan (psikomotor) (Juhji, 2016:61).

Dari berbagai pendapat di atas, maka dapat diketahui bahwa peran guru dalam dunia pendidikan sangat urgen. Peran tersebut tidak bisa dianggap remeh, karena guru adalah orang tua kedua bagi anak di sekolah. Sebagai orang tua, guru menjadi sosok yang digugu, ditiru dan dicontoh oleh anak didik. Guru berperan menanamkan nilai (value) serta membangun karakter (character building) peserta didik secara berkelanjutan, dan guru juga sebagai pendorong atau motivator bagi anak didik dalam proses pembelajaran dan melalui interaksi yang bernilai edukatif di sekolah.

\section{Hubungan Guru dan Orang Tua dalam Pendidikan}

Orang tua merupakan mitra kerja yang utama bagi guru dalam pendidikan anak. Komunikasi yang efektif antara orang tua dan guru dibutuhkan dalam rangka menyamakan persepsi kedua belah pihak tentang hal yang dibutuhkan dalam pendidikan anak. Keduanya harus saling membantu dan mengetahui bagaimana upaya penanganan pembinaan anak di sekolah, keterlibatan peserta didik dalam proses belajar mengajar, pola interaksi dan komunikasi selama di sekolah dan masalah yang ditemukan di sekolah. Begitu juga sebaliknya, pihak sekolah mengetahui apa dan bagaimana yang terjadi di rumah terutama terkait dengan kegiatan bermain anak di luar rumah, aktivitas belajar di rumah, interaksi dengan sesama 
anggota keluarga dan problem yang muncul selama berada di rumah. Menumbuhkan hubungan guru dan orang tua merupakan hal yang dianggap penting dalam pengembangan sekolah sebagai komunitas belajar. Komunikasi antara sekolah dan keluarga sangat diperlukan sehingga dapat memicu keterlibatan orang tua dalam proses pembelajaran. Orang tua memperoleh informasi tentang hal-hal yang dilakukan dan diperoleh anaknya, sementara guru memperoleh data tentang aktivitas siswanya saat bermain dan belajar di rumah. Disadari atau tidak, komunikasi antara orang tua dan guru mulai terjalin sejak hari pertama orang tua menginjakkan kaki di sekolah. Kesan pertama yang muncul sangat mempengaruhi perspektif orang tua terhadap sekolah. Senyuman dan keramahan yang ditunjukkan oleh guru, suasana sekolah dan kebersihan sekolah sangat mempengaruhi pandangan orang tua. Lingkungan sekolah yang ramah menunjukkan besarnya penghargaan sekolah tentang pentingnya komunikasi dengan orang tua (Pusitaningtyas, 2016).

\section{Kegiatan yang Relevan dengan Interaksi Edukatif}

Apabila kita memandang belajar-mengajar sebagai suatu proses, maka ada empat unsur fundamental dalam kegiatan tersebut. Pertama, berkenaan dengan tujuan dari proses belajarmengajar atau proses pembelajaran, kedua, mengenai isi atau bahan pembelajaran, ketiga mengenai metode dan alat pembelajaran dan keempat berkenaan dengan penilaian dalam pembelajaran. Keempat unsur tersebut saling mempengaruhi satu sama lain. Interaksi siswa dan guru dibangun diatas dasar empat unsur tersebut. Dalam interaksi tersebut siswa diarahkan guru untuk mencapai tujuan pembelajaran, melalui bahan pembelajaran, melalui bahan pembelajaran, melalui bahan pembelajaran yang dipelajari oleh siswa dengan menggunakan berbagai metode dan alat untuk kemudian dinilai ada tidaknya perubahan pada diri siswa setelah ia menyelesaikan proses belajar mengajar tersebut. Keberhasilan interaksi guru dan siswa, salah satu diantaranya bergantung pada bentuk komunikasi yang digunakan guru pada saaat ia mengajar. Oleh karenanya guru harus memiliki kemampuan dalam hal keterampilan dasar mengajar yang baik (Sudirman, 1987).

Biasanya interaksi edukatif sering kita temui dalam proses pembelajaran. Dalam proses pembelajaran akan terlibat dua komponen utama yang memiliki peran yang penting demi terwujudnya sebuah interaksi yang bernilai edukatif, yaitu komponen pendidik dan peserta didik. Ciri-ciri interaksi edukatif yaitu menurut Hasibuan dan Moedjiono ada beberapa ciri yaitu: 1) Ada tujuan yang ingin dicapai, 2) Ada bahan atau pesan yang menjadi isi interaksi, 3) Ada pelajar yang aktif mengalami, 4) Ada guru yang melaksanakan, 5) Ada metode untuk mencapai tujuan, 6) Ada situasi yang memungkinkan proses belajar mengajar dengan baik, 7) Ada penilaian terhadap hasil interaksi (Hasibuan, 1992).

Dari penjelasan di atas, maka dapat diketahui bahwa semua kegiatan yang memiliki tujuan, yang memiliki pesan, adanya individu atau kelompok yang aktif, adanya individu atau kelompok yang melaksanakan, adanya metode untuk mencapai tujuan, adanya situasi dan kondisi yang memungkinkan untuk terlaksanannya proses belajar mengajar yang baik, adanya penilaian atau evaluasi terhadap hasil interaksi, maka kegiatan itu bisa tergolong 
kegiatan yang relevan atau sesuai dengan kegiatan yang berupa interaksi yang bernilai edukatif.

\section{Kesimpulan}

Interaksi edukatif adalah hubungan dua arah antara guru dan anak didik dengan sejumlah norma sebagai mediumnya untuk mencapai tujuan pendidikan. Guru dan orang tua merupakan unsur yang terlibat dalam interaksi edukatif, karena keduanya memiliki peran penting dalam terbentuknya sebuah interaksi yang bernilai edukatif. Orang tua memiliki tanggung jawab terhadap anaknya khususnya yang berusia sekolah dasar. Tanggung jawab tersebut meliputi tanggung jawab pendidikan dan penanaman akhlak, pembinaan jasmani dan rohani. Peran guru dalam lembaga pendidikan yaitu sebagai korektor, inspirator, informator, organisator, motivator, inisiator, fasiliator, pembimbing, demonstrator, pengelola kelas, mediator, supervisor, dan evaluator.

Hubungan orang tua dan guru yaitu orang tua merupakan mitra kerja yang utama bagi guru dalam pendidikan anak. Komunikasi yang efektif antara orang tua dan guru dibutuhkan dalam rangka menyamakan persepsi kedua belah pihak tentang hal yang dibutuhkan dalam pendidikan anak. Keduanya harus saling membantu dan mengetahui bagaimana upaya penanganan pembinaan anak di sekolah, keterlibatan peserta didik dalam proses belajar mengajar, pola interaksi dan komunikasi selama di sekolah dan masalah yang ditemukan di sekolah.

Semua kegiatan yang memiliki tujuan, yang memiliki pesan, adanya individu atau kelompok yang aktif, adanya individu atau kelompok yang melaksanakan, adanya metode untuk mencapai tujuan, adanya situasi dan kondisi yang memungkinkan untuk terlaksanannya proses belajar mengajar yang baik, adanya penilaian atau evaluasi terhadap hasil interaksi, maka kegiatan itu bisa tergolong kegiatan yang relevan atau sesuai dengan kegiatan yang berupa interaksi yang bernilai edukatif.

\section{Daftar Pustaka}

Anis Pusitaningtyas, Pengaruh Komunikasi Orang Tua dan Guru terhadap Kreativitas Siswa, Jurnal: International Seminar on Generating Knowledge Through Research, UUM-UMSIDA， 25-27 October 2016, Universiti Utara Malaysia, Malaysia.

Ardayani, Lili. 2017. Proses Pembelajaran dalam Interaksi Edukatif, Jurnal: Itqan, Vol. 8 No. 2.

Asrori, Mohammad. 2009. Psikologi Pembelajaran, Bandung: Bumi Kencana.

Eva Santika, Gusti Budjang, Izhar Salim, Interaksi Edukatif Guru Dan Siswa dalam Diskusi Kelompok Kecil di SMA Islamiayah, (Jurnal: JIPP, Vol. 4 No. 10, 2015), hal 2-3.

Fariyatul Fahyani, Eni \& Istikomah. 2016. Psikologi Belajar \& Mengajar: Kunci Sukses Guru dan Peserta Didik dalam Interaksi Edukatif, Sidoarjo: Nizamia Learning Center.

Gustina. 2009. Lingkungan Keluarga sebagai Wahana Sosial dan Interaksi Edukatif bagi Anak: Suatu Tinjauan Sosio-Edukasi Religius terhadap Pendidikan dalam Keluaraga, Jurnal: Ta'dib Vol. 12 No. 2.

Hany Almasitoh, Ummu. 2014. Guru sebagai Pelaku Utama Proses Pendidikan, Jurnal: Magistra, No.87.

Hasibuan dan Moedjiono. 1992. Proses Belajar Mengajar, Bandung: Remaja Rosdakarya Offset.

Juhji. 2016. Peran Urgen Guru Dalam Pendidikan, Jurnal: Studia Didaktika, Vol. 10 No. 1, 2016.

Nazarudin. M. (2018). Pola Keriasama Guru dan Orang Tua dalam Meningkatkan Mutu Pendidikan di MIN 2 Kota Palembang. Intizar, 24(2), 211-218. https://doi.org/https://doi.org/10.19109/inti zar.v24i2.3259

Padjrin, P. (2016). Pola Asuh Anak dalam 
Perspektif Pendidikan Islam. Jurnal Intelektualita: Keislaman, Sosial Dan Sains, 5(1), $\quad 1 \quad-14$. https://doi.org/https://doi.org/10.19109/int elektualita.v5i1.720

Rahman, N. (2009). Manaiemen Pembelaiaran; Implementasi Konsep, Karakteristik dan Metodologi Pendidikan Agama Islam di Sekolah Umum. Cet I Yogyakarta: Pustaka Felicha.

Sudirman. 1987. Ilmu Pendidikan, Jakarta: Remaja Karya.

Syahraeni, Andi. 2015. Tanggung Jawab Keluarga dalam Pendidikan Anak, Jurnal: UIN-Alaudin.ac.id.

Usman, A. Samad. 2017. Tanggung Jawab Orang Tua terhadap Pendidikan Anak dalam Perspektif Islam, Jurnal:Ar-Raniry. 